\title{
FOUNDER AS STEWARD OR AGENT? A STUDY OF FOUNDER OWNERSHIP AND FIRM VALUE
}

\author{
Alexandra Dawson \\ Associate Professor \\ Concordia University \\ 1455 De Maisonneuve Blvd. West \\ Montreal, QC, Canada H3G 1M8 \\ Tel: (514) 848-2424 \\ E-mail: alexandra.dawson@concordia.ca \\ Imants Paeglis \\ Associate Professor \\ Concordia University \\ 1455 De Maisonneuve Blvd. West \\ Montreal, QC, Canada H3G 1M8 \\ Tel: (514) 848-2424 \\ E-mail: imants.paeglis@concordia.ca \\ Nilanjan Basu \\ Associate Professor \\ Concordia University \\ 1455 De Maisonneuve Blvd. West \\ Montreal, QC, Canada H3G 1M8 \\ Tel: (514) 848-2424 \\ E-mail: nilanjan.basu@concordia.ca
}

Final version: $\underline{\text { http://journals.sagepub.com/doi/pdf/10.1177/1042258717725522 }}$

Citation for published version: A Dawson, I Paeglis, N Basu (2018). Founder as Steward or Agent? A Study of Founder Ownership and Firm Value. Entrepreneurship Theory and Practice, DOI: $10.1080 / 13691066.2018 .1516358$

\section{Acknowledgements}

The authors are grateful to the associate editor and anonymous reviewers for their insightful suggestions. Basu and Paeglis gratefully acknowledge financial support from the Social Sciences and Humanities Research Council of Canada (SSHRC) and the Desjardins Centre for Innovation in Business Finance. Paeglis also gratefully acknowledges financial support from the Institut de Finance Mathematique de Montreal (IFM2). 


\title{
FOUNDER AS STEWARD OR AGENT? A STUDY OF FOUNDER OWNERSHIP AND FIRM VALUE
}

\begin{abstract}
This study addresses the relationship between founder ownership and firm value in young and entrepreneurial businesses. We argue that a stewardship effect prevails when founders have low or high levels of ownership whilst an agency effect prevails at intermediate levels. Using a dataset of 1,269 firms with 11,645 firm-year observations, we find support for our hypothesis that there is a convex relationship between founder ownership and firm value. The agency effect at intermediate founder ownership is consistent with evidence indicating that these firms display lower leverage, greater unrelated diversification, and higher disproportionate board representation.
\end{abstract}

\section{INTRODUCTION}

In this study we contribute to the debate about the relationship between founder ownership and firm value by focusing on public firms that are relatively young and entrepreneurial. Firm value has long been a key concern for entrepreneurship and management scholars (van Essen, Carney, Gedajlovic, \& Heugens, 2015). We focus on founders because they play a key role in their business in its various stages. At startup they shape the firm's initial structure, strategy, and vision (Nelson, 2003). They continue to influence the firm over time as they become part of its upper echelon as owners, managers, or directors (Nelson, 2003). At initial public offering (IPO), founders are often the largest shareholders (Bruton, Filatotchev, Chahine, \& Wright, 2010) and this affects valuation and early returns (Certo, Covin, Daily, \& Dalton, 2001). Newly public firms do not yet enjoy an established reputation and therefore rely heavily on that of their founder (Basu, Dimitrova, \& Paeglis, 2009). After going public, firms often retain their founders as influential shareholders, managers, or directors (e.g., Anderson \& Reeb, 2003a; Morck, Shleifer, \& Vishny, 1988). 
Several studies have focused on the relationship between ownership structure in general and firm value after IPO (e.g., Anderson \& Reeb, 2003a; Anderson, Duru, \& Reeb, 2009; Miller, Le Breton-Miller, Lester, \& Cannella, 2007; Morck et al., 1988; Villalonga \& Amit, 2006). Our study differs from prior work in three ways. First, most previous research has not focused exclusively on founder ownership, considering founders together with other insider owners (Morck et al., 1988), corporate insiders (McConnell \& Servaes, 1990), or large owners including banks, institutional investors, other nonfinancial companies, and governments (Thomsen \& Pedersen, 2000). Instead, we focus solely on founder ownership, excluding other large blockholders. Second, scholars have often considered founder status as a dummy variable, comparing subsamples of founder vs. nonfounder firms (Fahlenbrach, 2009; Miller et al., 2007; Villalonga \& Amit, 2006), without taking into account the size of the founder's equity ownership. Instead, we consider the full range of founder ownership and its relationship with firm value. Third, previous studies have considered very large and mature businesses (Fortune 500 in Villalonga \& Amit, 2006 and Morck et al., 1988; Fortune 1000 in Miller et al., 2007; S\&P 500 in Anderson \& Reeb, 2003a). This focus can lead to a selection bias, since these are firms that have grown rapidly and exclude those with lower growth (Adams, Almeida, \& Ferreira, 2009). Furthermore, these firms represent a small proportion of all firms, and generally founders are no longer present or retain small portions of equity. As noted by Walters, Kroll, \& Wright (2010: 572), "reliance on large, established firms has left the research community vulnerable to offering prescriptions that might not apply in other contexts." Instead, we consider a sample of firms that have been public for less than 20 years. Thus our findings are more representative of the overall population of founder-controlled firms and allow us to provide a novel perspective on the role of the founder in determining firm value. 
We make two contributions to the entrepreneurship field. First, we find a convex relationship between founder ownership and firm value, indicating that firms with low or high levels of founder ownership have higher value than do firms with intermediate levels of founder ownership. Second, we complement prior research on public firm value by using a unique sample of relatively young US firms, which have been public for less than 20 years, and in many of which the founder continues to play an important role.

The remainder of the article is structured as follows. First, we develop our theoretical background and formulate hypotheses. Second, we illustrate our methodology, explaining how we put together our sample, introducing variables, and presenting models and results. Third, we discuss findings. Finally, we offer concluding remarks, including limitations, future research opportunities, and practical implications.

\section{THEORY AND HYPOTHESES}

Prior research suggests that founders have positive effects on firm value. Villalonga and Amit (2006: 404) suggested that active founders create value for shareholders because they "bring valuable skills to their firms" by being "inspiring leaders, great visionaries, or exceptionally talented scientists", allowing them to generate benefits for the business that are greater than costs of expropriation. Anderson and Reeb (2003a: 1317) concluded that founders are associated with greater firm value, because they "bring unique, value-adding skills to the firm that result in superior accounting performance and market valuations". Morck et al. (1988) reported that having a founding family member as a top officer was associated with higher firm value among newer firms, in which founders are more likely to be present, because the entrepreneurial ability of the founder is a valuable asset. Miller et al. (2007) found higher firm value for firms retaining 
their founders. Adams et al. (2009) found a positive causal effect of founder/CEOs on firm performance. Fahlenbrach (2009) concluded that founder-CEO firm have higher Tobin's q than nonfounder firms.

In our study, we take a finer-grained look at founder ownership by considering the size of the founder's stake and its relationship with firm value. We draw on two main management theories, agency and stewardship theory. Agency theory is the predominant theoretical framework in prior research on the relationship between ownership structure and firm value (e.g., Thomsen and Pedersen, 2000). According to this view, individuals owning less than $100 \%$ of a firm's equity are likely to act as agents and pursue their own interests, divergent from those of other shareholders. According to a stewardship view, which draws on a psychological perspective, individuals will invest greatly in their organization, to the benefit of all (Le BretonMiller \& Miller, 2009). This alternative viewpoint has been helpful in explaining entrepreneurial, pro-organizational behaviors (Corbetta \& Salvato, 2004). It has been said that "agency theory is more likely to describe executives who did not create an organization" (Wasserman, 2006: 960). However we argue below that both theories, agency and stewardship, are applicable depending on the ownership stake of a founder.

At startup founders typically own $100 \%$ of the business and act in the best interest of the organization, in other words as stewards, rather than engaging in individualistic and self-serving behaviors (Davis, Schoorman, \& Donaldson, 1997). Individuals act as stewards when they experience psychological ownership towards an organization (Pierce, Kostova, \& Dirks, 2003), which, as founders, they view as 'their baby' (Litwinski, 1947). Founders typically experience psychological ownership — which is related to but goes beyond legal ownership — towards their business because they exercise control over it, are closely associated with and have intimate 
knowledge of the business, experience a sense of responsibility, and invest their whole self in their venture (Pierce et al., 2001; 2003). Because they have created their business, founders develop a strong identification with and extraordinary commitment towards the organization (Davis et al., 1997; Nelson, 2003). As their firm grows, founders' feelings of ownership towards the business are enhanced because the growth of possessions produces positive and uplifting effects (Formanek, 1991), possibly as a result of self-enhancing biases, invested effort, controllability, and social approval (Beggan, 1991). In sum, psychological ownership creates a strong sense of attachment to the organization, making the founder more likely to act as a steward and in the best interest of the organization (Davis et al., 1997). ${ }^{1}$

Even if their ownership is not $100 \%$, but is still high, founders tend to perceive their stake to be greater than it really is because of the time, effort, and sweat equity that they have put into the venture and their attachment to the business. By maintaining a strong attachment towards the business, they will continue acting as an owner even after relinquishing part of their ownership (Arthurs \& Busenitz, 2003). Following this reasoning, when founders have high ownership in the firm, we expect them to act as stewards towards the business, serving the interests of the firm. It has been said that "[e]xtraordinary power accrues to owners who hold large absolute or relative stakes" (Nelson, 2003: 710). With high ownership share, founders - who even after IPO tend to hold board positions and/or act as CEO of their firm — retain the power to collect information and monitor managers thus exercising greater influence (Bruton et al., 2010; Filatotchev, Wright, \& Arberk, 2006; Morck \& Yeung, 2003) and reducing managers' tendency to act as

\footnotetext{
${ }^{1}$ Even from an agency perspective, in a wholly-owned firm that is managed by the owner, we can assume that the owner "will make operating decisions that maximize his utility" (Jensen \& Meckling, 1976: 11) and will therefore try and avoid bad management decisions because he/she will bear $100 \%$ of the monetary costs of such a decision.
} 
opportunistic agents and engage in inefficient strategies such as consumption of perquisites (Demsetz \& Lehn, 1985; Hoskisson, Hitt, Johnson, \& Grossman, 2002). At the same time we expect founders to exert greater effort because they have a reputational stake in the firm (Jayaraman, Khorana, Nelling, \& Covin, 2000). When founders own a significant fraction of their firm's equity, their financial attachment is likely to lead to better firm value (Oswald \& Jahera, 1991) because founders' personal fortunes tend to be tied to those of their firms. This induces founders to work more diligently and make greater investments in developing and exercising their managerial skills. In addition, with high founder ownership, the founder's share of the costs of perquisite consumption will increase, leading to lower incentives to engage in it (Jensen \& Meckling, 1976). All these factors are likely to lead to greater convergence of interests between founder and minority shareholders, helping to overcome principal-principal problems and leading to better firm value (Berle \& Means, 1932; Dalton, Daily, Certo, \& Roengpitya, 2003; Jensen \& Meckling, 1976; Morck et al., 1988).

What happens when the founder owns a relatively smaller share of the equity in the firm he/she started? Research shows that the greater the amount of control, the higher is the psychological ownership towards a target (Pierce et al., 2001) and therefore the more likely that a founder will act as a steward. Conversely, when an individual is unable to exercise control over an object, the object is no longer perceived as being part of the self (Lewis \& Brook, 1974). Feelings of ownership vary according to the amount of control individuals can exercise, not only across individuals but also within a single individual at different points in time. In fact, feelings of ownership towards a target do not necessarily last forever. Individuals may experience a 'decoupling process' whereby they no longer feel a sense of ownership for targets that were once integrated into their self-concept. This can happen for a number of reasons, including loss of 
control, entailing the disappearance of a key route to ownership over the target (Pierce et al., 2001; 2003). Founders who identify less closely with the organization have to share the strategic decision making and experience reduced intrinsic motivation and organizational commitment. Therefore, if founders retain intermediate levels of equity, their psychological ownership and consequent stewardship behavior towards the business will be limited (Wasserman, 2006).

In this situation, agency theory becomes more applicable (Davis et al., 1997). As a result we expect founders with intermediate levels of ownership to behave more like agents than stewards, and to pursue individual self-interest over the interests of the organization (Wasserman, 2006), becoming entrenched. We define entrenchment as founders' ability to use their influence in the firm for their own benefit at the expense of minority shareholders, while avoiding being monitored or disciplined by them (e.g., being ousted or forced to change their actions). Prior research offers evidence of entrenched founders. Morck et al. (1988) concluded that some founder/managers can be entrenched with relatively small equity stakes. Other studies (Johnson, Magee, Nagarajan, \& Newman, 1985; Salas, 2010; Slovin \& Sushka, 1993) have reported positive share price reaction to deaths of CEOs who were also founders, suggesting that they may not have been effective firm monitors and may have been extracting private benefits to the exclusion of other shareholders.

Entrenchment can result in corporate assets being less valuable (Morck et al., 1988). Because the founder and the other shareholders have diverging goals, this situation creates principal-principal agency problems. How do founders extract private benefits? Founders created the business, therefore they have well established networks of exchange relationships and can use their leverage over others who may have to sanction their decisions (Barkema \& Pennings, 1998). This can allow founders to expropriate the wealth of minority shareholders and 
take advantage of public market investors (Bruton et al., 2010; Fama \& Jensen, 1983; Morck et al., 1988) through transfer of resources from the firm to the founder at nonmarket prices that are favourable to the founder, high compensation, dilution of minority shareholders, insider trading, loan guarantees using the firm's assets as collateral, strategies that benefit personal or family agendas at the expense of firm value such as excessive diversification, and so on (Johnson, La Porta, Lopez de Silanes, \& Shleifer, 2000). These principal-principal conflicts affect the dynamics of the corporate governance process, which in turn shape the firm's strategy and ultimately its value (Young, Peng, Ahlstrom, Bruton, \& Jiang, 2008).

We do not anticipate either stewardship or agency effects to be evident when founders have very limited ownership in the firm. In this situation, regardless of their objectives or motivation, founders have reduced power in the firm due to their low ownership. The market for corporate control would correct for any excessive agency costs caused by founders (with low levels of ownership) acting in their self-interest (Dalton, Hitt, Certo, \& Dalton, 2007) through several possible actions such as hostile takeovers, voluntary mergers, leveraged buyouts, asset sales and so on (Jensen, 1986).

In sum, we hypothesize a convex, or U-shaped, relationship between founder ownership and firm value. At low and high levels of founder ownership we expect higher firm value than at intermediate levels of founder ownership. Formally stated:

Hypothesis 1: There is a convex (U-shaped) relationship between founder ownership and firm value, with the lowest value occurring at intermediate levels of ownership.

\section{Underlying Mechanisms at Intermediate Levels of Ownership}


In this section we explore mechanisms that may be associated with and help explain the hypothesized agency effect at intermediate levels of founder ownership. Specifically, we consider three additional pieces of evidence that may be associated with the entrenchment of founders with intermediate ownership: leverage, unrelated diversification (Anderson \& Reeb, 2003b), and 'disproportionate board representation', i.e. control of the board of directors in excess of voting control (Villalonga \& Amit, 2009).

Leverage. Businesses with entrenched founders who have strong incentives to expropriate wealth from minority shareholders will want to avoid risk by using sources of capital with relatively low probability of default. Similarly, entrenched CEOs who are not pressured by compensation incentives or active monitoring tend to avoid the use of debt (Berger, Ofek, \& Yermack, 1997). This means entrenched founders prefer to avoid leveraging their capital structure (Anderson \& Reeb, 2003b) in order to elude the risk of losing their wealth through bankruptcy due to excessive corporate debt (Stulz, 1988) and to protect their underdiversified human capital (Fama, 1980). They may also want to avoid performance pressures associated with commitments deriving from issuance of debt (Jensen, 1986). Formally stated:

Hypothesis 2: Firms with intermediate levels of founder ownership will have the lowest leverage, compared to firms with low or high levels of founder ownership.

Diversification. Entrenched founders will engage in diversification in order to lower risk (Anderson \& Reeb, 2003b) seeing that they hold much of their wealth in one firm. Ownership concentration has been found to be associated with the propensity to engage in corporate diversification (Amihud \& Lev, 1981; Denis, Denis, \& Sarin, 1997). Entrenched founders may also engage in 'empire building' through diversification in order to increase their status, power, 
and security (Hoskisson et al., 2002). Thus, we expect firms with intermediate levels of founder ownership to be more diversified, consistent with entrenchment of such founders. Formally stated:

Hypothesis 3: Firms with intermediate levels of founder ownership will have the highest corporate diversification, compared to firms with low or high levels of founder ownership.

Disproportionate board representation. Controlling shareholders can decide who is on the board of directors (Young et al., 2008). Entrenched founders can expropriate wealth from minority shareholders if they hold so-called 'disproportionate representation on the board of directors', i.e. control of the board of directors in excess of voting control, allowing them to elect a large proportion of the board, thereby controlling the firm's management, strategic direction, and voting agenda (Villalonga \& Amit, 2009). If their control of the board of directors is greater than their voting control, founders' influence will exceed their ownership rights (Faccio, Lang, \& Young, 2001). A board that has few independent directors and is dominated by the founder (and his/her family) will give the latter a disproportionate voice in the firm's decision making, increasing the likelihood of powerful founders expropriating the firm's wealth and resources for their private benefit (Anderson \& Reeb, 2004). Therefore, we expect firms with intermediate levels of founder ownership to have the highest probability of using disproportionate board representation as a control-enhancing mechanism, consistent with the entrenchment of such founders. Formally stated: 
Hypothesis 4: Firms with intermediate levels of founder ownership will have the highest disproportionate board representation, compared to firms with low or high levels of founder ownership.

\section{METHOD}

\section{Sample}

To test the hypotheses in this study, we used a hand-collected sample of 1,269 firms that have been public for less than 20 years. We started with all US IPOs of common equity between 1993 and 1996, obtained from the SDC/Platinum New Issues database. We eliminated the following: real estate investment trusts (REITs), closed-end funds, unit offerings, equity carve-outs, financial firms (SIC codes between 6000 and 6999), utilities, foreign firms, leveraged buyouts, and roll-ups; firms that were not found in the Center for Research in Security Prices (CRSP) or COMPUSTAT databases; and firms for which there was a discrepancy between the first date of trading provided by CRSP and SDC. We were left with a total of 1,269 firms. Of these, 1,017 were firms in which the founder was still present (founder firms) and 431 were firms in which the founder was no longer present (nonfounder firms). We then manually collected ownership data for each of these firms for up to 19 years after their IPO. Of the 1,269 firms at the time of IPO, 104 survived until the $18^{\text {th }}$ listing anniversary (those that did not survive were delisted, merged with other firms, or went out of business). Our final sample for the main test consists of 11,645 firm-year observations with available ownership and accounting data. In Table 1 we report the number of founder-and nonfounder firms for the IPO year and each of the 19 subsequent years. For all empirical tests, we use the largest number of observations possible. 
As can be seen in Table 2, which reports the distribution of our sample by the level of founder ownership, founder ownership exceeds $50 \%$ for more than $9 \%$ of our sample.

Insert Table 2 Here

\section{Identification of Founder}

We identified founders of our sample firms using the information in the management sections of IPO prospectuses. The data on founder ownership were collected from the IPO prospectus and the subsequent proxy statements. We considered related founders (e.g., two siblings) as one block because family members are assumed to act in unison. This assumption is in line with much of the family business literature, which has found the family organization to build cohesiveness as a way to maintain a sense of belonging to the family, sustain its values and aspirations, and benefit by sharing in the family wealth (e.g., Aronoff, 1998; Sharma, 2004). On average, among founder firms, the founder owned $27.6 \%$ of voting rights in the firm at IPO. Table 3 includes a list and definitions of all variables.

Insert Table 3 Here

\section{Variables}

We defined founder ownership as the fraction of voting rights controlled by the founder and his/her family. To allow for non-linearity in the relationship between ownership and firm value, similar to other studies (e.g., Chahine, Filatotchev, \& Zahra, 2011), we also used squared ownership $^{2}$. In line with a majority of studies on firm value (e.g., Anderson et al., 2009), we used Tobin's q as our measure of firm value. As a proxy for a firm's valuation, Tobin's q is relatively

\footnotetext{
${ }^{2}$ We also used cubed ownership, based on Morck et al. (1988), as illustrated in the Models and Results section.
} 
high when the firm's expected future performance is superior to that of comparable firms due to factors such as effective management and other intangible assets that are not reflected in financial statements (Morck et al., 1988). Leverage is defined as the ratio of book value of longterm debt to total assets. We measured unrelated corporate diversification using a dummy variable that takes on a value of one if the firm has sales in more than one Fama-French 48 industry group, and zero otherwise (Fama \& French, 1997). Fama and French's (1997) algorithm reclassifies existing SIC codes into 48 industry groupings. It has been found to work as well as SIC (Bhojraj, Lee, \& Oler, 2003) and provides us with a tighter definition of unrelated diversification as it uses 48 instead of $80+$ groups for 2 -digit SIC. Disproportionate board representation refers to the founder's excess board control relative to his/her voting rights (Villalonga \& Amit, 2009).

\section{Control Variables}

In order to take into account other potential effects on firm value, we introduced several control variables relating to firm and industry characteristics. To control for the potential impact of the presence of a dual class share structure, we used the wedge (Gompers, Ishii, \& Metrick, 2010). We used firm size to control for potential differences in economies of scale and for the fact that it may be easier for founders to own a large portion of smaller firms and benefit from asymmetric information (McConnell \& Servaes, 1990). Because there may be less available information on younger firms, we controlled for differences in the level of asymmetric information using firm age (Ritter, 1984). Firm age may also be associated with a reduction in the main founder's entrepreneurial talent as time goes on (Morck et al., 1988). We controlled for growth opportunities, which may affect firm value, using two variables: sales growth (Villalonga \& 
Amit, 2006) and the ratio of $R \& D$ expenditure to net sales (Anderson \& Reeb, 2003a;

McConnell \& Servaes, 1990). We included leverage to account for any change in firm value due

to potential tax benefits that arise from debt as well as for the information conveyed by the use of debt (Fama \& French, 1998). We used the industry median market-to-book ratio (with industry defined using Fama \& French, 1997) to control for variation in the firm value across industries (Short \& Keasey, 1999). We used year dummies to control for variation in firm value across years.

We included three ownership-related variables to control for various other elements of ownership structure: ownership of unaffiliated blockholders to control for potential monitoring benefits (Anderson \& Reeb, 2003a); cofounder ownership to control for the potential influence a cofounder may have on firm value as they may complement the main founder's resources (Kor \& Mahoney, 2000; Lechler, 2001) thus benefiting firm value or collude with the main founder to consume private benefits (Zwiebel, 1995); and the difference between ownership of inside blockholders and that of the founder to control for the potential influence of nonfounder inside blockholders on firm value (Anderson \& Reeb, 2003a). Finally, we included the following control variables for the regressions of leverage, diversification, and disproportionate board representation on founder ownership (Anderson \& Reeb, 2003b; Villalonga, 2004): collateral, cash ratio, EBIT, NYSE, industry median leverage, and industry percentage diversified.

\section{Models and Results}

All of our results were obtained using the statistical package STATA. Table 4 shows descriptive statistics, including means and standard deviations of the variables and correlations among them. Tobin's q is quite high $($ Mean $=2.59$, S.D. $=1.47)$, as can be expected seeing that our sample is 
overwhelmingly made up of young, entrepreneurial public firms in which the founder is still present.

\section{Insert Table 4 Here}

In the first three columns of Table 5 we present results of the multi-level Tobit regression (starting with reduced form models including control variables) with Tobin's q as dependent variable (with t-statistics calculated using heteroscedasticity-adjusted (White) standard errors). Tobit regression is appropriate for our analysis since our dependent variable is censored (Sanders \& Carpenter, 2003). As can be seen in column 3, the coefficient estimate of founder ownership is negative $(b=-.69, p<.05)$, while that of founder ownership squared is positive $(b=1.37, p<$ .001). These results imply a statistically significant and convex (U-shaped) relationship between founder ownership and firm value (see top left panel in Figure 1). ${ }^{3}$ Thus, Hypothesis 1 is supported. The relationship between ownership and firm value reaches its minimum at $25.2 \%$ of founder ownership. The curve displayed in the top left panel in Figure 1 may provide a visual impression that with lower founder ownership there is limited effect on firm value, however this is not the case. In firms with $25.2 \%$ founder ownership, Tobin's q is lower than in firms with negligible founder ownership by .086. This represents about a $3.1 \%$ decline in Tobin's q relative to firms with negligible founder ownership. Given the average firm size of about $\$ 416$ million, this is economically significant as the decline translates into a loss of about $\$ 12.7$ million in terms of market value. Similarly, by the time founder ownership reaches majority $(50 \%)$, the

\footnotetext{
${ }^{3}$ We also re-estimated this regression for subsamples of firms that survive to their $6^{\text {th }}, 12^{\text {th }}$, and $18^{\text {th }}$ listing anniversaries. Our results remain qualitatively unchanged for these subsamples and all indicate a statistically significant convex relationship between founder ownership and firm value.
} 
firm value increases by .09, which represents a $3.2 \%$ increase from the lowest point. For an average firm, this translates into a $\$ 13.2$ million increase in market capitalization.

A natural question that arises from our results is whether they are driven by the participation of the founder in the executive decision making of the firm rather than by founder ownership. In order to address this issue, we ran regressions to control for the founder's involvement in the management of the firm, using a founder-non-CEO dummy as well as interactions of this dummy with founder ownership and founder ownership squared. Results suggest that our findings apply to both owners who are also CEOs and owners who are not CEOs, although the negative influence of founder ownership (at low and intermediate levels) and the positive one (at higher levels of founder ownership) are more pronounced when the founder is the $\mathrm{CEO}$ of the firm. ${ }^{4}$

Most of the control variables are significant. Sales growth, $R \& D$, and industry Tobin's $q$ have a positive and significant effect on firm value as would be expected, while leverage has a negative effect ( $p<.01$ for sales growth, leverage and industry Tobin's q; $p<.05$ for R\&D). With respect to firm characteristics, firm age is negative and significant $(p<.05)$. This result points towards a reduction of growth opportunities as firms become older (Evans, 1987), leading to lower firm value. Also, in older firms the entrepreneurial talent of the founder may be less valuable (Morck et al., 1988).

Insert Table 5 Here

Insert Figure 1 Here

\footnotetext{
${ }^{4}$ In unreported results, we also include a founder-non-CEO dummy as an additional control variable in our Table 5 specifications and find that it is statistically insignificant.
} 
Endogeneity. There has been a debate in the literature regarding the direction of causality between ownership structure and value (Demsetz \& Lehn, 1985; Thomsen \& Pedersen, 2000). Ownership structure could be endogenous, meaning that founders may actually sell shares if firm value is decreasing or buy shares if firm value is increasing (Demsetz, 1983). To address this possible endogeneity bias, we estimated the relationship between founder ownership and firm value using a two-stage least squares (2SLS) regression model. In order to implement this model, we required instrumental variables that are correlated with and are thus good predictors of founder ownership, while remaining free of the reverse causality that is the potential source of the endogeneity bias. Following Gompers et al. (2010), we chose firm characteristics that would provide strong incentives for a founder to retain significant ownership and control in the firm and, similar to them, we identified the following instrumental variables: (1) Profit_rank, (2) Percent_count, (3) Percent_sales, and (4) Sales_regional. In addition, and as recommended by them, we statistically tested for the validity of our instruments.

The instruments are defined in Table 3. We measured all the instrumental variables at the earliest point in time when public data was available on our firms rather than at the time when we observe Tobin's q. Similar to Gompers et al. (2010), we argue that the main decision by the founder with respect to his/her level of ownership is taken at the time of going public while the value of the firm changes from year to year in response to changes in economic conditions. This indicates that our instrumental variables could be correlated with founder ownership but not with firm value. To further ensure the appropriateness of our instruments we performed the following tests. The Durbin-Wu-Hausman test suggested that founder ownership is not exogenous ( $p<$ .01). Further, as noted by Bascle (2008), for 2SLS estimation to produce consistent and efficient estimates, chosen instruments have to be relevant (strong) and exogenous. Results of the Stock 
and Yogo (2005) test suggested that our instruments are strong. Finally, we tested the exogeneity of our instruments using Hansen's J-test. We failed to reject the exogeneity of our instruments as a group $(p=.525)$. We also replicated this test for all possible subsets of instruments. In all cases, we failed to reject exogeneity of our instruments. Overall our tests indicated that the instruments are appropriate.

The fourth column of Table 5 presents the second stage results of the 2SLS analyses, which are consistent with the Tobit results. In particular, we find that the convex relationship between founder ownership and firm value exists even after controlling for endogeneity.

Firm survival and selection bias. Our results until this point indicate that founder ownership is significantly related to firm value. Since a firm's performance and its survival in a competitive market are closely linked to its value, it could be reasonably expected that founder ownership will also affect firm survival. As a result, the inclusion of firms in our sample could itself be affected by founder ownership. Econometrically, this is a problem since it could result in a biased sample that would question the reliability of our results. We address this issue in our analysis in Table 6 through the use of Heckman's (1979) selection model. This model allows us to examine the relationship between founder ownership and firm survival as well as to correct for the influence of any selection bias on the relationship between founder ownership and Tobin's q. In particular, we jointly estimate the selection model and the Tobit model from Table 5 using full information maximum likelihood (see Li \& Prabhala, 2007).

In column 1 of Table 6 we report the results of a probit model that estimates the probability of a firm surviving until the next year as a function of founder ownership, the square of founder ownership, and other variables that are potential determinants of firm survival. While the literature on firm survival has considered a large number of potential predictors, we focus on 
the ones that are consistently found to be important predictors (Manjon-Antolin \& ArauzoCarod, 2008; Romanelli, 1989) and that can be collected for our fairly large sample of firms.

Our results indicate that founder ownership predicts firm survival with the probability of firm survival increasing with founder ownership at low levels of ownership and then decreasing at higher levels of founder ownership (the coefficient estimate on founder ownership squared, however, is not statistically significant). In column 2 of Table 6 , we revisit our conclusions from Table 5 after adjusting for any sample selection bias that is created by the impact of founder ownership on firm survival (and therefore by extension on inclusion in our sample). The results continue to indicate a significant convex relationship between founder ownership and firm value. Moreover, the Wald test of independent equations indicates that the error terms in the two equations are not significantly related. Therefore, although founder ownership does impact the survival of firms in our sample, this relationship does not bias our results and our conclusions from Table 5 are robust to this correction.

\section{Insert Table 6 Here}

Underlying mechanisms. Table 7 presents the results of the pooled year fixed effects regression analyses with leverage, diversification, and disproportionate board representation as dependent variables. Using multi-level Tobit regression with leverage as the dependent variable (see columns 1, 2, and 3), we find that the coefficient estimate of the founder ownership is negative $(b=-.20, p<.001)$, while that of the founder ownership squared is positive $(b=.35, p<$ .001). These results imply a statistically significant and convex (U-shaped) relationship between founder ownership and leverage, with lower leverage occurring at intermediate levels of founder ownership (see top right panel in Figure 1). Thus, Hypothesis 2 is supported. Our results suggest 
that the relationship between founder ownership and leverage reaches its minimum at $28.6 \%$ of founder ownership.

Using logit regression with diversification as the dependent variable (see columns 4, 5, and 6), we find that the coefficient estimate of the founder ownership is positive ( $\mathrm{b}=.82, p<$ $.05)$, while that of the founder ownership squared is negative $(\mathrm{b}=-1.36, p<.05)$. These results imply a statistically significant and concave (inverted U-shaped) relationship between founder ownership and the probability of observing a diversified firm, with greater diversification occurring at intermediate levels of founder ownership (see bottom left panel in Figure 1). ${ }^{5}$ Thus, Hypothesis 3 is supported. Our results suggest that the relationship between founder ownership and probability of observing a diversified firm reaches its maximum at $30.2 \%$ of founder ownership.

Using logit regression with disproportionate board representation as the dependent variable (see columns 7,8 , and 9), we find that the coefficient estimate of the founder ownership is positive $(\mathrm{b}=25.08, p<.001)$, while that of the founder ownership squared is negative $(\mathrm{b}=$ $72.43, p<.001)$. These results imply a statistically significant and concave (inverted U-shaped) relationship between founder ownership and the probability of observing a disproportionate board representation, with greater disproportionate board representation occurring at intermediate levels of founder ownership (see bottom right panel in Figure 1). Thus, Hypothesis 4 is supported. Our results suggest that the relationship between founder ownership and

\footnotetext{
${ }^{5}$ Following Zelner (2009) and Bowen (2012), we have also included 95\% confidence intervals for the regression models estimated using logit.
} 
probability of observing a disproportionate board representation reaches its maximum at 17.3\% of founder ownership. ${ }^{6}$

\section{Insert Table 7 Here}

Cubic relationship. As an alternative post hoc analysis, we repeated our analysis using a cubic specification for founder ownership, similar to Morck et al. (1988). We find that the cubic term is insignificant even at the $10 \%$ level. At the same time, the linear and quadratic terms remain statistically significant. Moreover, the addition of the cubic term leaves the Wald-chi ${ }^{2}$ practically unchanged. In contrast, the addition of both the linear and the quadratic terms increases the Wald-chi ${ }^{2}$. Therefore, from the perspectives of both overall model fit and significance of individual coefficient estimates, the quadratic specification appears to be the one that is most appropriate for the data ${ }^{7}$.

We performed a similar analysis for the hypotheses regarding leverage, diversification, and disproportionate board representation. The conclusions with respect to leverage mirror those for Tobin's q. The cubic term remains insignificant and has a minimal impact on the overall goodness of fit. The findings are somewhat different with respect to diversification and disproportionate board representation and, in each of these cases, the coefficient estimate of the cubic term is statistically significant. In the case of diversification, the overall model fit as measured by the pseudo R-squared does not change much with the addition of the cubic term.

\footnotetext{
${ }^{6}$ Mediation analysis suggested no mediating effect for leverage (perhaps not surprisingly, given that leverage on its own is one of the strongest determinants of Tobin's q). We found partial mediation for diversification, and some (albeit statistically insignificant) evidence of partial mediation for disproportionate board control.

${ }^{7}$ We also estimated a piecewise linear regression and the quadratic specification remained the most appropriate for our data.
} 
For disproportionate board representation, the cubic term appears to have a substantial impact on the pseudo R-squared that is comparable in magnitude to that attributable to the linear and cubic terms ${ }^{8}$. We interpret these findings in our discussion below.

\section{DISCUSSION}

Founders represent an important class of large shareholders with unique incentive structures and a strong voice in the firm (Anderson \& Reeb, 2003a). This study analyzes the impact of founder ownership on firm value, using a unique, hand-collected dataset of young and entrepreneurial firms that have been public for less than 20 years. Although prior research has indicated a positive effect associated with founder ownership, those studies have focused on very large firms in which the founder typically retains limited equity. Thus our sample of young public firms provides a unique setting that allows us to analyze founder effect on a broader range of ownership than previously done. As alluded to earlier, our sample contains a significant number of observations for which founder ownership exceeds 50\%. Founders are still present in $70 \%$ of our sample firms at the time of the IPO and in 50\% of the firms 12 years after the IPO. Also, the founder owns $28.3 \%$ of the firm at IPO and still owns $20.3 \% 12$ years after the IPO (with median values of $21.0 \%$ and $11.6 \%$, respectively). These values are all higher than those reported in previous studies (Anderson \& Reeb, 2003a; Fahlenbrach, 2009; Villalonga \& Amit, 2006).

Our findings indicate that the relationship between founder ownership and firm value is not linear. Controlling for several variables relating to firm and industry characteristics, we find a U-shaped relationship between founder ownership and firm value. A likely explanation for our findings is that there is a stewardship effect dominating at high (controlling) levels of founder

\footnotetext{
${ }^{8}$ Further details about our findings can be obtained by contacting the corresponding author.
} 
ownership, while an agency effect dominates at intermediate levels. This reasoning seems to be supported by additional tests on our sample showing that founders with intermediate levels of ownership are more likely to decrease their ownership stakes over time, suggesting that indeed these individuals have diminished commitment and attachment to their firms as they tend to sell off equity over time. Additionally, founders with high levels of ownership are more likely to maintain or even increase their ownership stakes, which seems to confirm their stewardship towards the firm. At the same time, we also find that founders with high level of ownership are less likely to serve as CEOs of their firm, suggesting that they are hiring professional management for the benefit of the business as they recognize their limited managerial abilities (e.g., Boeker \& Karichalil, 2002).

Unlike other studies (e.g., McConnell \& Servaes, 1990; Short \& Keasey, 1999), here we are able to exclude possible endogeneity through 2SLS analysis — in other words, the possibility that the positive (negative) relationship we find between founder ownership and firm value may reflect founders maintaining higher ownership stakes in more (less) valuable firms. When the founder has a low-to-intermediate stake (below $25.2 \%$ in our sample), there appears to be an agency effect with founders being psychologically detached from the business (Pierce et al., 2001; Wasserman 2006) and exercising self-interest by pursuing their own agenda and consuming perquisites (Jensen \& Meckling, 1976). Consequently there is an adverse effect on market valuation. Based on these explanations, our results show that founders with an ownership stake of $25.2 \%$ tend to be the most entrenched because their stake is large enough to entrench but not large enough for a stewardship effect to prevail.

Beyond a certain point ( $25.2 \%$ in our sample), a stewardship effect seems to prevail over an agency effect because founders have greater incentives to maximize firm value as their 
psychological ownership of their business is greater (Pierce et al., 2001). This is consistent with the explanation that insiders with large shareholdings are effective monitors of management's actions. Fan and Wong (2002: 406) also found that ownership concentration has an incentive alignment effect and that when owners' share ownership is 'beyond the minimum level needed for effective control' this 'improves the alignment of interests between the controlling owner and the minority shareholders and reduces the effects of entrenchment'. The greater the percentage of shares owned, the greater the motivation and the financial interest of the founder to monitor the management team and to exercise influence over the board of directors (Demsetz, 1986; Morck et al., 1988).

Our findings are consistent with the strategic decision making that is typical of entrenched founders. We explored three mechanisms that are typical of such founders and that help explain the relatively lower firm value at intermediate levels of founder ownership. Their inflection points are close to that we found for the relationship between founder ownership and firm value. Because of the undiversified nature of their holdings and their desire for firm survival, entrenched founders have strong incentives to minimize firm risk (Anderson \& Reeb, 2003b). They achieve this through lower leverage and greater diversification. Also, they often control the board through disproportionate board representation (Villalonga \& Amit, 2009).

Our findings differ somewhat from Morck et al.'s (1988) who found a cubic relationship between managerial ownership and firm value. In our study, both from the overall model fit perspective as well as from the significance of individual coefficients perspective, the quadratic specification appears to be the most appropriate for the data. We believe this is the case for the following three reasons. First, we focus on founders and their ownership rather than on insider/managerial ownership (where insiders may or may not be the firm's founders). Second, 
we analyze smaller and younger firms than those included in Morck et al.'s (1988) sample, where founders still play a strong leadership role $(67.2 \%$ of founders in our sample are also CEO). Third, as opposed to Morck et al.'s (1988) sample, our sample includes a significant number of firms with founder ownership above $50 \%$. As a result, we are better able to address the impact of founder ownership on firm value when the founders own a majority of firm equity. These differences, i.e. the presence and influence of the founder, help explain why we do not find a cubic relationship similar to that found by Morck et al. (1988). The addition of the cubic term with respect to diversification shows possibly the largest difference from our main results. There is a clear increase in the propensity to diversify at very high levels of founder ownership that is discernible when ownership reaches about $70 \%$. We speculate that founders who own such a substantial portion of the firm could often face the problem of having significant undiversified personal wealth that is tied up in the firm. In such situations, we suspect the founder faces pressure to diversify the firm as the only way to diversify his or her personal portfolio. However, our results suggest that such diversification has a minimal impact on Tobin's q. Finally, with regard to disproportionate board representation, any differences between the quadratic and cubic specification are primarily manifested at ownership levels greater than $90 \%$ and are also quite small in magnitude. Therefore, although the statistical analysis indicates that the cubic term may have a role to play, its magnitude indicates that it is a lower order effect. Our findings may warrant further research into the effects found.

\section{CONCLUDING REMARKS}

This study analyzes the impact of founder ownership on firm value, which has to date been investigated mainly by looking at large, mature public firms in which founders retain limited 
ownership stakes. By focusing on firms that have been public for less than 20 years, and in which founders often retain relatively high ownership and CEO status, we find a U-shaped relationship between founder ownership and firm value. A likely explanation is that an agency effect dominates at low-to-intermediate levels of founder ownership, while a stewardship effect dominates at intermediate-to-high levels, when founders are controlling owners. Our findings contribute to the ongoing debate questioning the universal applicability of agency theory to the ownership-value relationship (Dalton et al., 2003; Lane, Cannella, \& Lubatkin, 1998). By complementing an undersocialized agency theory approach, which neglects the diverse identities of stakeholders (Aguilera \& Jackson, 2003), with stewardship theory we support the view that 'the complexities of organizational life [should not be] ignored' (Davis et al., 1997: 696).

Our conclusions should be considered in light of the study's limitations. First, although we followed firms for up to 19 years after IPO, we focus on the cross-sectional dimension and do not take into account the effect of time. Prior research suggests that most founders who take their firm public do so for the first time and, therefore, are inexperienced in their new environment (Certo et al., 2001). As time goes by, they may become more effective leaders or may leave the firm altogether. Other evidence points to the contrary, with founders displaying better performance earlier in their careers and worse performance as time goes by (GomezMejia, Nunez-Nickel, \& Gutierrez, 2001; Johnson et al., 1985; Morck et al., 1988). Second, we focus on the ownership by the main founder and, although we have cofounder ownership as a control variable, we do not explore the interactions that take place in a team when there are multiple founders. Their occurrence would have effects in terms of team composition and dynamics (Napier \& Gershenfeld, 1993). There may also be divisions or fault lines among cofounders (Lau \& Murnighan, 1998), depending on demographic or other characteristics. 
Cofounders' decision to monitor or collude with the main founder warrants further study. Third, although most prior studies have considered Tobin's q as a measure of firm value, there are potential shortcomings deriving from the use of this measure because of its dependence on market price and therefore on the short term fluctuations in the stock market. An alternative measure of performance that has been used in the literature is the return on firm's assets (e.g., Bruton et al., 2010). As discussed in Elsayed (2007), Tobin's q has an advantage in that it is forward looking and incorporates future profits and the ability of the firm to improve its performance over time. Since our study focuses on the role of the founder in shaping the nature of the firm and thus the long term performance of the firm, a forward looking measure is especially important for us. Furthermore, we mitigate the dependence of Tobin's q on market price by employing a fairly long time series of 19 years and controlling for year fixed effects.

We have identified several avenues for further research. First, researchers might consider further explanations, beyond the ones we have considered. For example, founders may create barriers for bidding agents (takeovers), pay special dividends, conduct business with familyrelated parties, give themselves higher salaries and compensation packages, or reduce the presence of independent directors on the board (Anderson \& Reeb, 2003a, 2004; Holderness \& Sheehan, 1988). Or controlling founders may decide to align themselves with minority shareholders because of costs of expropriation, for example if higher dividends are being paid out (Faccio et al., 2001; La Porta, Lopez-de-Silanes, Shleifer, \& Vishny, 2000) or depending on market conditions seeing that insiders generally expropriate less when the market is thriving and more when the market is deteriorating (Chen, Chen, \& Wei, 2009; Durnev \& Kim, 2005). Further mechanisms may apply when the founder is also CEO, for example their (financial or nonfinancial) background (Andrews \& Welbourne, 2000); the perceived threat to founder-CEO 
compensation, which may affect founder-CEO’s risk taking (Larraza-Kintana, Wiseman, Gomez-Mejia, \& Welbourne, 2007); internal factors such as size of founding team, top management team independence (Jain \& Tabak, 2008) or human resource practices, including rewards systems or CEO stock options (Certo, Daily, Cannella, \& Dalton, 2003; Welbourne \& Andrews, 1996).

Second, scholars may want to investigate whether the declining slope for low-tointermediate levels of founder ownership is an indication of the founder's limited entrepreneurial ability (Morck et al., 1988), which has a negative impact on the firm's value as his/her stake increases. Third, future research may focus more on the ownership structure and its relationship with firm value, by considering, for example, team size (Lechler, 2001). Fourth, it may be interesting to investigate situational variables, such as the presence and degree of formal control mechanisms in the firm, as these may influence an organization's culture, level of trust, and intrinsic motivation (Davis et al., 1997; Wasserman, 2006). Finally, it would be interesting to investigate further the relationship between founder ownership and firm survival (Li and Prabhala, 2007).

With regard to practical implications, the results of this study are of interest to various stakeholders. Financial investors can benefit from knowing whether or not public firms with high levels of founder ownership outperform or underperform firms with low levels of founder ownership. Potential managers and employees will also be interested, because their compensation may be linked to the firm's value, which is related to ownership structure. 


\section{REFERENCES}

Adams, R., Almeida, H., \& Ferreira, D. (2009). Understanding the relationship between founder-CEOs and firm performance. Journal of Empirical Finance, 16, 136-150.

Aguilera, R.V. \& Jackson, G. (2003). The cross-national diversity of corporate governance: Dimensions and determinants. Academy of Management Review, 28, 447-465.

Amihud, Y. \& Lev, B. (1981). Risk reduction as a managerial motive for conglomerate mergers. Bell Journal of Economics, 12, 605-617.

Anderson, R.C., Duru, A., \& Reeb, D.M. (2009). Founders, heirs, and corporate opacity in the United States. Journal of Financial Economics, 92, 205-222.

Anderson, R.C. \& Reeb, D.M. (2003a). Founding family ownership and firm performance: Evidence from the S\&P 500. Journal of Finance, 58, 1301-1328.

Anderson, R.C. \& Reeb, D.M. (2003b). Founding-family ownership, corporate diversification, and firm leverage. Journal of Law and Economics, 46, 653-684.

Anderson, R.C. \& Reeb, D.M. (2004). Board composition: Balancing family influence in S\&P 500 firms. Administrative Science Quarterly, 49, 209-237.

Andrews, A.O. \& Welbourne, T.M. (2000). The people/performance balance in IPO firms: The effect of the Chief Executive Officer's financial orientation. Entrepreneurship Theory and Practice, 25, 93-106.

Aronoff, C.E. (1998). Megatrends in family business. Family Business Review, 11, 181-185.

Arthurs, J.D \& Busenitz, L.W. (2003). The boundaries and limitations of agency theory and stewardship theory in the venture capitalist/entrepreneur relationship. Entrepreneurship Theory and Practice, 28, 145-162. 
Barkema, H.G \& Penning, J.M. (1998). Top management pay: Impact of overt and covert power. Organization Studies, 19, 975-1003.

Bascle, G. (2008). Controlling for endogeneity with instrumental variables in strategic management research. Strategic Organization, 6, 285-327.

Basu, N., Dimitrova, L., \& Paeglis, I. (2009). Family control and dilution in mergers. Journal of Banking and Finance, 33, 829-841.

Beggan, J.K. (1991). Using what you own to get what you need: The role of possessions in satisfying control motivation. Journal of Social Behavior and Personality, 6, 129-146.

Berger, P.G, Ofek E., \& Yermack, D.L. (1997). Managerial entrenchment and capital structure decisions. Journal of Finance, 52, 1411-1438.

Berle, A.A. Jr. \& Means, G.C. (1932). The Modern Corporation and Private Property. New York: Macmillan.

Bhojraj, S., Lee, C., \& Oler, D.K. (2003). What's my line? A comparison of industry classification schemes for capital market research. Journal of Accounting Research, 41, $745-774$.

Boeker, W. \& Karichalil, R. (2002). Entrepreneurial transitions: Factors influencing founder departure. Academy of Management Journal, 45, 818-826.

Bowen, H.P. (2012). Testing moderating hypotheses in limited dependent variable and other nonlinear models secondary versus total interactions. Journal of Management, 38, 860889.

Bruton, G., Filatotchev, I., Chahine, S., \& Wright, M. (2010). Governance, ownership structure and performance of IPO firms: The impact of different types of private equity investors and institutional environments. Strategic Management Journal, 31, 491-509. 
Certo, S.T., Daily, C.M., Cannella, A.A., \& Dalton, D.R. (2003). Giving money to get money: How CEO stock options and CEO equity enhance IPO valuations. Academy of Management Journal, 46, 643-653.

Certo, S.T, Covin, J.G, Daily, C.M, \& Dalton, D.R. (2001). Wealth and the effects of founder management among IPO-stage new ventures. Strategic Management Journal, 22, 641658.

Chahine, S., Filatotchev, I., \& Zahra, S.A. (2011). Building perceived quality of founderinvolved IPO firms: Founders effects on board selection and stock market performance. Entrepreneurship Theory and Practice, 35, 319-335.

Chen, K.C., Chen, Z., \& Wei, K.J. (2009). Legal protection of investors, corporate governance, and the cost of equity capital. Journal of Corporate Finance, 15, 273-289.

Corbetta, G. \& Salvato, C. (2004). Self-serving of self-actualizing? Models of man and agency costs in different types of family firms: A commentary on Comparing the agency costs of family and non-family firms: Conceptual issues and exploratory evidence.

Entrepreneurship Theory and Practice, 28, 355-362.

Dalton, D.R, Daily, C.M, Certo, S.T, \& Roengpitya, R. (2003). Meta-analyses of financial performance and equity: Fusion or confusion?. Academy of Management Journal, 46, 1326.

Dalton, D.R, Hitt, M.A, Certo, S.T, \& Dalton, C.M. (2007). The fundamental agency problem and its mitigation: Independence, equity, and the market for corporate control. Academy of Management Annals, 1, 1-64.

Davis, J.H, Schoorman, F.D., \& Donaldson, L. (1997). Toward a stewardship theory of management. Academy of Management Review, 22, 20-47. 
Demsetz, H. (1983). The structure of ownership and the theory of the firm. Journal of Law and Economics, 26, 375-390.

Demsetz, H. (1986). Corporate control, insider trading, and rates of return. The American Economic Review, 76, 313-316.

Demsetz, H. \& Lehn, K. (1985). The structure of corporate ownership: Causes and consequences. Journal of Political Economy, 93, 1155-1177.

Denis, D.J, Denis, D.K, \& Sarin, A. (1997). Agency problems, equity ownership, and corporate diversification. Journal of Finance, 52, 135-160.

Durnev, A., Kim, E.H. (2005). To steal or not to steal: firm attributes, legal environment, and valuation, Journal of Finance, 60, 1461-1493.

Elsayed, K. (2007). Does CEO duality really affect corporate performance?. Corporate Governance: An International Review, 15, 1203-1214.

Evans, D.S. (1987). Reviewed tests of alternative theories of firm growth. Journal of Political Economy, 95, 657-674.

Faccio, M., Lang L.H.P, \& Young, L. (2001). Dividends and expropriation. American Economic Review, 91, 54-78.

Fahlenbrach, R. (2009). Founder-CEOs, investment decisions, and stock market performance. Journal of Financial and Quantitative Analysis, 44, 439-466.

Fama, E.F. (1980). Agency problems and the theory of the firm. Journal of Political Economy, $88,288-307$.

Fama, E.F \& French, K.R. (1997). Industry costs of equity. Journal of Financial Economics, 43, $153-193$. 
Fama, E.F. \& French, K.R. (1998). Taxes, financing decisions, and firm value. Journal of Finance, 53, 819-843.

Fama, E.F \& Jensen, M. (1983). The separation of ownership and control. Journal of Law and Economics, 26, 301-325.

Fan, J.P. \& Wong, T.J. (2002). Corporate ownership structure and the informativeness of accounting earnings in East Asia. Journal of Accounting and Economics, 33, 401-425.

Filatotchev, I., Wright, M., \& Arberk, M. (2006). Venture capitalists, syndication and governance in initial public offerings. Small Business Economics, 26, 327-350.

Formanek, R. (1991). Why they collect: Collectors reveal their motivations. Journal of Social Behavior and Personality, 6, 275-286.

Gomez-Mejia, L., Nunez-Nickel, M., \& Gutierrez, I. (2001). The role of family ties in agency contracts. Academy of Management Journal, 44, 81-95.

Gompers, P.A., Ishii, J., \& Metrick, A. (2010). Extreme governance: An analysis of dual class firms in the United States. Review of Financial Studies, 23, 1051-1088.

Heckman, J. (1979). Sample selection as a specification error. Econometrica, 47, 153-161.

Holderness, C., Sheehan, D. (1988). The role of majority shareholders in publicly held corporations: An exploratory analysis. Journal of Financial Economics, 20, 317-346.

Hoskisson, R.E., Hitt, M.A., Johnson, R.A., \& Grossman, W. (2002). Conflicting voices: The effects of institutional ownership heterogeneity and internal governance on corporate innovation strategies. Academy of Management Journal, 45, 697-716.

Jain, B.A., \& Tabak, F. (2008). Factors influencing the choice between founder versus nonfounder CEOs for IPO firms. Journal of Business Venturing, 23, 21-45. 
Jayaraman, N., Khorana, A., Nelling, E., \& Covin, J. (2000). CEO founder status and firm financial performance. Strategic Management Journal, 21, 1215-1224.

Jensen, M.C. (1986). Agency costs of free cash flow, corporate finance, and takeovers. The American Economic Review, 76, 323-339.

Jensen, M.C \& Meckling, W. (1976). Theory of the firm: Managerial behavior, agency costs and ownership structure. Journal of Financial Economics, 3, 305-360.

Johnson, S., La Porta, R., Lopez de Silanes, F., \& Shleifer, A. (2000). Tunneling. American Economic Review, 90, 22-27.

Johnson, B., Magee, R., Nagarajan, N., \& Newman, H. (1985). An analysis of the stock price reaction to sudden executive deaths: Implications for the management labor market. Journal of Accounting and Economics, 7, 151-174.

Kor, Y.Y \& Mahoney, J.T. (2000). Penrose's resource-based approach: The process and product of research creativity. Journal of Management Studies, 37, 109-139.

Lane, P.J., Cannella, A.A. Jr, \& Lubatkin, M.H. (1998). Agency problems as antecedents to unrelated mergers and diversification: Amihud and Lev reconsidered. Strategic Management Journal, 19, 555-578.

La Porta, R., Lopez-De-Silanes, F., \& Shleifer, A. (1999). Corporate ownership around the world. Journal of Finance, 54, 471-518.

La Porta, R. Lopez-de-Silanes, F., Shleifer, A., \& Vishny, R.W. (2000). Agency problems and dividend policies around the world. Journal of Finance, 55, 1-33.

Larraza-Kintana, M., Wiseman, R.M., Gomez-Mejia, L.R., \& Welbourne, T.M. (2007).

Disentangling compensation and employment risks using the behavioral agency model. Strategic Management Journal, 28, 1001-1019. 
Lau, D.C. \& Murnighan, J. K. (1998). Demographic diversity and faultlines: The compositional dynamics of organizational groups. Academy of Management Review, 23, 325-340.

Le Breton-Miller, L. \& Miller, D. (2009). Agency vs. stewardship in public family firms: A social embeddedness reconciliation. Entrepreneurship Theory and Practice, 33, 11691191.

Lechler, T. (2001). Social interaction: A determinant of entrepreneurial team venture success. Small Business Economics, 16, 263-278.

Lewis, M. \& Brook, J. (1974). Self, other, and fear: Infants reactions to people. In Lewis, M. and Rossenblum, L. S. (Eds.), The Origins of Fear. New York: Wiley, 165-194.

Li, K. \& Prabhala, N. (2007). Self-selection models in corporate finance, in B. Espen Eckbo (Ed.), Handbook of Corporate Finance: Empirical Corporate Finance, Elsevier, Amsterdam.

Litwinski, L. (1947). The psychology of “mine”. Philosophy, 22, 240-251.

Manjon-Antolin, M.C. \& Arauzo-Carod, J.M. (2008). Firm survival: methods and evidence. Empirica, 35, 1-24.

McConnell, J.J. \& Servaes, H. (1990). Additional evidence on equity ownership and corporate value. Journal of Financial Economics, 27, 595-612.

Miller, D., Le Breton-Miller, I., Lester, R.H., \& Cannella, A.A. (2007). Are family firms really superior performers?. Journal of Corporate Finance, 13, 829-858.

Morck, R. \& Yeung, B. (2003). Agency problems in large family business groups. Entrepreneurship Theory and Practice, 27, 367-382.

Morck, R.K, Shleifer, A., \& Vishny, R. (1988). Management ownership and market valuation: An empirical analysis. Journal of Financial Economics, 20, 293-315. 
Napier, R. \& Gershenfeld, M. (1993). Groups, theory and experience. Boston, MA: Houghton Mifflin.

Nelson, T. (2003). The persistence of founder influence: Management, ownership, and performance effects at initial public offering. Strategic Management Journal, 24, 707724.

Oswald, S.L. \& Jahera, J.S. Jr (1991). The influence of ownership on performance: An empirical study. Strategic Management Journal, 12, 321-326.

Pierce, J.L., Kostova, T., \& Dirks, K.T. (2001). Toward a theory of psychological ownership in organizations. Academy of Management Review, 26, 298-310.

Pierce, J.L., Kostova, T., \& Dirks, K.T. (2003). The state of psychological ownership: Integrating and extending a century of research. Review of General Psychology, 7, 84107.

Ritter, J. (1984). The hot issue market of 1980. Journal of Business, 57, 215-241.

Romanelli, E. (1989). Environments and strategies of organization start-up: Effects on early survival. Administrative Science Quarterly, 34, 369-387.

Salas, J.M. (2010). Entrenchment, governance, and the stock price reaction to sudden executive deaths. Journal of Banking and Finance, 34, 656-666.

Sanders, W.G., \& Carpenter, M.A. (2003). Strategic satisficing? A behavioral-agency theory perspective on stock repurchase program announcements. Academy of Management Journal, 46, 160-178.

Sharma, P. (2004). An overview of the field of family business studies: Current status and directions for the future. Family Business Review, 17, 1-36. 
Short, H. \& Keasey, K. (1999). Managerial ownership and the performance of firms: Evidence from the UK. Journal of Corporate Finance, 5, 79-101.

Slovin, M.B. \& Sushka, M.E. (1993). Ownership concentration, corporate control activity, and firm value: Evidence from the death of inside blockholders. Journal of Finance, 48, $1293-1321$.

Stock, J. \& Yogo, M. (2005). Testing for weak instruments in IV regressions. In Andrews, D., \& Stock, J. (Eds.), Identification and Inference for Econometrics Models: Essays in Honor of Thomas Rothenberg. Cambridge, UK: Cambridge University Press, 80-108.

Stulz, R. (1988). Managerial control of voting rights: Financing policies and the market for corporate control. Journal of Financial Economics, 20, 25-54.

Thomsen, S. \& Pedersen, T. (2000). Ownership structure and economic performance in the largest European companies. Strategic Management Journal, 21, 689-705.

van Essen, M., Carney, M., Gedajlovic, E.R., \& Heugens, P.P.M.A.R. (2015). How does family control influence firm strategy and performance? A meta-analysis of US publicly listed firms. Corporate Governance: An International Review, 23, 3-24.

Villalonga, B. (2004). Does diversification cause the "diversification discount"?. Financial Management, 33, 5-27.

Villalonga, B. \& Amit, R. (2006). How do family ownership, control, and management affect firm value?. Journal of Financial Economics, 80, 385-417.

Villalonga, B. \& Amit, R. (2009). How are US family firms controlled?. Review of Financial Studies, 22, 3047-3091.

Walters, B.A, Kroll, M., \& Wright, P. (2010). The impact of TMT board member control and environment on post-IPO performance. Academy of Management Journal, 53, 572-595. 
Wasserman, N. (2006). Stewards, agents, and the founder discount: Executive compensation in new ventures. Academy of Management Journal, 49, 960-976.

Welbourne, T.M., \& Andrews, A.O. (1996). Predicting the performance of initial public offerings: should human resource management be in the equation?. Academy of Management Journal, 39, 891-919.

Young, M.N., Peng, M.W., Ahlstrom, D., Bruton, G.D., \& Jiang, Y. (2008). Corporate governance in emerging economies: A review of the principal-principal perspective. Journal of Management Studies, 45, 196-220.

Zelner, B.A. (2009). Using simulation to interpret results from logit, probit, and other nonlinear models. Strategic Management Journal, 30, 1335-1348.

Zwiebel, J. (1995). Block investment and partial benefits of corporate control. Review of Economic Studies, 62, 161-185. 
Table 1. Sample distribution: distribution of founder ownership over time

\begin{tabular}{|c|c|c|c|c|c|}
\hline \multirow[b]{2}{*}{ Year } & \multirow[b]{2}{*}{$\begin{array}{l}\text { Non- } \\
\text { founder } \\
\text { firms }\end{array}$} & \multirow[b]{2}{*}{$\begin{array}{c}\text { Founder } \\
\text { firms }\end{array}$} & \multirow[b]{2}{*}{ Total firms } & \multicolumn{2}{|c|}{ Founder ownership } \\
\hline & & & & Average & Median \\
\hline IPO & 372 & 897 & 1,269 & $28.28 \%$ & $21.00 \%$ \\
\hline year 1 & 372 & 878 & 1,250 & $25.41 \%$ & $17.65 \%$ \\
\hline year 2 & 387 & 835 & 1,222 & $23.98 \%$ & $16.70 \%$ \\
\hline year 3 & 363 & 743 & 1,106 & $22.96 \%$ & $15.15 \%$ \\
\hline year 4 & 345 & 602 & 947 & $22.74 \%$ & $14.25 \%$ \\
\hline year 5 & 320 & 508 & 828 & $22.51 \%$ & $14.30 \%$ \\
\hline year 6 & 281 & 408 & 689 & $23.65 \%$ & $14.60 \%$ \\
\hline year 7 & 271 & 354 & 625 & $23.66 \%$ & $12.80 \%$ \\
\hline year 8 & 246 & 298 & 544 & $24.52 \%$ & $14.62 \%$ \\
\hline year 9 & 233 & 271 & 504 & $22.60 \%$ & $12.30 \%$ \\
\hline year 10 & 219 & 235 & 454 & $22.79 \%$ & $12.40 \%$ \\
\hline year 11 & 196 & 205 & 401 & $21.71 \%$ & $13.30 \%$ \\
\hline year 12 & 179 & 184 & 363 & $20.27 \%$ & $11.60 \%$ \\
\hline year 13 & 167 & 161 & 328 & $18.78 \%$ & $10.30 \%$ \\
\hline year 14 & 159 & 137 & 296 & $17.92 \%$ & $9.00 \%$ \\
\hline year 15 & 158 & 117 & 275 & $17.44 \%$ & $7.30 \%$ \\
\hline year 16 & 136 & 108 & 244 & $17.44 \%$ & $6.80 \%$ \\
\hline year 17 & 96 & 58 & 154 & $17.98 \%$ & $7.83 \%$ \\
\hline year 18 & 64 & 40 & 104 & $15.13 \%$ & $6.96 \%$ \\
\hline year 19 & 28 & 14 & 42 & $15.10 \%$ & $8.10 \%$ \\
\hline Total & & & 11,645 & & \\
\hline
\end{tabular}


Table 2: Distribution of sample by the level of founder ownership

\begin{tabular}{ccc}
\hline ownership & $\begin{array}{c}\text { nr of } \\
\text { firm- } \\
\text { bracket }\end{array}$ & $\begin{array}{c}\text { percentage } \\
\text { of total } \\
\text { sample }\end{array}$ \\
\hline & & \\
0 & 4,553 & $39.10 \%$ \\
$0-5 \%$ & 1,659 & $14.25 \%$ \\
$5-10 \%$ & 1,139 & $9.78 \%$ \\
$10-15 \%$ & 708 & $6.08 \%$ \\
$15-20 \%$ & 560 & $4.81 \%$ \\
$20-25 \%$ & 492 & $4.22 \%$ \\
$25-30 \%$ & 369 & $3.17 \%$ \\
$30-35 \%$ & 351 & $3.01 \%$ \\
$35-40 \%$ & 223 & $1.91 \%$ \\
$40-45 \%$ & 229 & $1.97 \%$ \\
$45-50 \%$ & 249 & $2.14 \%$ \\
$50-60 \%$ & 407 & $3.50 \%$ \\
$60-70 \%$ & 343 & $2.95 \%$ \\
$70-80 \%$ & 155 & $1.33 \%$ \\
$>80 \%$ & 208 & $1.79 \%$ \\
Total & $\mathbf{1 1 , 6 4 5}$ & \\
\hline & &
\end{tabular}


Table 3. List of variables

\begin{tabular}{|c|c|}
\hline Variables & Definitions \\
\hline & Ownership variables \\
\hline \multirow[t]{2}{*}{ Founder own } & Percentage of voting rights controlled by the founder and his/her family \\
\hline & Dependent variables \\
\hline Tobin’s q & $\begin{array}{l}\text { Ratio of the sum of market value of equity and book value of long term debt } \\
\text { to the sum of book values of equity and long term debt }\end{array}$ \\
\hline Leverage & Ratio of book value of long term debt to total assets \\
\hline Diversification & $\begin{array}{l}\text { Dummy variable ( } 1=\text { if the firm reports operations in more than one industry; } \\
0=\text { otherwise) }\end{array}$ \\
\hline \multirow[t]{2}{*}{$\begin{array}{l}\text { Disproportionate board } \\
\text { representation }\end{array}$} & $\begin{array}{l}\text { Dummy variable ( } 1=\text { if the presence of family members on the board of } \\
\text { directors leads to an excess board control (relative to the founder's voting } \\
\text { rights); } 0=\text { otherwise) }\end{array}$ \\
\hline & Control variables \\
\hline Wedge & $\begin{array}{l}\text { Difference between the percentage of voting and cash flow rights controlled } \\
\text { by the founder }\end{array}$ \\
\hline Firm size & Natural logarithm of book value of total assets (in millions of $\$$ ) \\
\hline Firm age & $\begin{array}{l}\text { Natural logarithm of one plus the number of years between either the year of } \\
\text { incorporation or the start of operations, whichever is earlier, and the time of } \\
\text { the proxy statement filing date }\end{array}$ \\
\hline Sales growth & Percentage change in sales over the previous year \\
\hline$R \& D$ & Ratio of R\&D to firm sales ( $=0$ if $R \& D$ expenditures were missing) \\
\hline Industry median Tobin's q & $\begin{array}{l}\text { Median Tobin's q for all COMPUSTAT firms in the same year and Fama- } \\
\text { French } 48 \text { industry group }\end{array}$ \\
\hline Year dummy & $\begin{array}{l}\text { Dummy variable ( } 1=\text { if the observation belongs to a calendar year } t \\
0=\text { otherwise) }\end{array}$ \\
\hline Unaffiliated block own & $\begin{array}{l}\text { Percentage of voting rights controlled by unaffiliated blockholders (those that } \\
\text { have no relation to the firm, other than their equity stake in the firm) }\end{array}$ \\
\hline Cofounder own & Percentage of voting rights controlled by cofounders \\
\hline Insider own less founder & $\begin{array}{l}\text { Percentage of voting rights controlled by inside blockholders (those that are } \\
\text { involved in management and/or governance of the firm) less founder } \\
\text { ownership }\end{array}$ \\
\hline Collateral & $\begin{array}{l}\text { Ratio of the sum of inventory and net property, plant, and equipment to total } \\
\text { assets }\end{array}$ \\
\hline Cash ratio & Ratio of cash and marketable securities to total assets \\
\hline EBIT & Ratio of earnings before interest and taxes (EBIT) to net sales \\
\hline NYSE & $\begin{array}{l}\text { Dummy variable }(1=\text { if the firm's stock trades on the New York Stock } \\
\text { Exchange (NYSE); } 0=\text { otherwise) }\end{array}$ \\
\hline Industry median leverage & $\begin{array}{l}\text { Median leverage for all COMPUSTAT firms in the same year and Fama- } \\
\text { French } 48 \text { industry group }\end{array}$ \\
\hline Industry percentage diversified & $\begin{array}{l}\text { Percentage of firms in the same Fama-French } 48 \text { industry group that are } \\
\text { diversified }\end{array}$ \\
\hline
\end{tabular}


Instrumental variables (2SLS model)

Profit_rank $\quad$ Firm's percentile ranking based on gross profit in its first year appearing in COMPUSTAT in the distribution of all other firms new to COMPUSTAT

Percent_count Percentage of firms located in the firm's region in the year prior to its first appearance in COMPUSTAT relative to all firms in

COMPUSTAT during that year. Region is defined as a metropolitan or micropolitan statistical area or a metropolitan division when one exists, and a county otherwise

Percent_sales

Percentage of sales by all firms located in the firm's region in the year prior to its first appearance in COMPUSTAT relative to all firms in

COMPUSTAT during that year

Sales_regional

Sales divided by total sales in this firm's region in its first year of appearing in COMPUSTAT

Selection variables (Heckman model)

Firm age at IPO

Number of years between either the year of incorporation or the start of operations, whichever is earlier, and the time of IPO

Years since IPO

Number of years between the time of IPO and the time of the proxy statement filing date

Industry sales growth

Growth rate in net sales for the median firm in the same Fama-French 48

industry group

Industry concentration

Herfindahl index computed based on net sales for all firms in the same Fama-French 48 industry group

High tech dummy

Dummy variable ( $1=$ if the firm is in a technology-related industry (as defined by Loughran and Ritter, 2004); $0=$ otherwise) 
Table 4. Descriptive statistics

\begin{tabular}{|c|c|c|c|c|c|c|c|c|c|c|c|c|c|c|c|c|c|}
\hline & Mean & S.D. & 1 & 2 & 3 & 4 & 5 & 6 & 7 & 8 & 9 & 10 & 11 & 12 & 13 & 14 & 15 \\
\hline 1Tobin's q & 2.59 & 1.47 & 1 & & & & & & & & & & & & & & \\
\hline 2 Leverage & .15 & .22 & -.24 & 1 & & & & & & & & & & & & & \\
\hline 3 Diversification & .25 & .43 & -.17 & .08 & 1 & & & & & & & & & & & & \\
\hline $\begin{array}{l}4 \text { Disproportionate board } \\
\text { representation }\end{array}$ & .31 & .46 & .06 & -.10 & -.05 & 1 & & & & & & & & & & & \\
\hline 5 Founder own & .14 & .21 & .00 & .09 & -.03 & -.14 & 1 & & & & & & & & & & \\
\hline 6 Founder own squared & .07 & .15 & -.01 & .13 & -.01 & -.21 & .94 & 1 & & & & & & & & & \\
\hline 7 Wedge & .01 & .07 & -.06 & .14 & .04 & -.12 & .51 & .62 & 1 & & & & & & & & \\
\hline 8 Firm size & 4.67 & 1.61 & -.22 & .36 & .29 & -.08 & .00 & .06 & .17 & 1 & & & & & & & \\
\hline 9 Firm age & 2.82 & .70 & -.26 & .11 & .24 & -.20 & .03 & .07 & .08 & .37 & 1 & & & & & & \\
\hline $10 \mathrm{R} \& \mathrm{D}$ & .20 & .45 & .22 & -.09 & -.15 & .12 & -.17 & -.14 & -.07 & -.23 & -.22 & 1 & & & & & \\
\hline 11 Unaffiliated block own & .17 & .17 & -.12 & .10 & .10 & .02 & -.32 & -.27 & -.10 & .19 & .15 & .07 & 1 & & & & \\
\hline 12 Industry median Tobin's q & 1.95 & .72 & .39 & -.18 & -.16 & .13 & -.12 & -.12 & -.08 & -.24 & -.28 & .46 & -.02 & 1 & & & \\
\hline 13 Cofounder own & .01 & .04 & .09 & -.06 & -.07 & .09 & .12 & .01 & -.02 & -.11 & -.14 & -.04 & -.14 & .03 & 1 & & \\
\hline 14 Insider own less founder & .08 & .14 & -.02 & -.01 & -.05 & -.15 & -.14 & -.14 & -.08 & -.14 & .01 & -.13 & -.22 & -.09 & .25 & 1 & \\
\hline 15 Sales growth & .46 & 1.20 & .21 & -.03 & -.10 & .08 & -.02 & -.03 & -.02 & -.11 & -.29 & .17 & -.07 & .17 & .04 & .02 & 1 \\
\hline
\end{tabular}

$\mathrm{N}=11,645$. Note: Correlations greater than .0175 or less than -.0175 are significant at $p<.05$ 
Table 5. Results of multi-level Tobit and 2SLS regressions of Tobin's q on founder ownership

\begin{tabular}{|c|c|c|c|c|}
\hline & (1) & (2) & (3) & (4) \\
\hline & Tobit & Tobit & Tobit & $2 S L S$ \\
\hline Founder own & & $.21 \dagger$ & $-.69 *$ & $-15.47 * *$ \\
\hline Founder own squared & & & $1.37 * * *$ & $33.48 * * *$ \\
\hline Wedge & & $-1.10 * *$ & $-1.40 * * *$ & $-19.27 * * *$ \\
\hline Firm size & $-.23 * * *$ & $-.22 * * *$ & $-.22 * * *$ & -.02 \\
\hline Firm age & $-.10^{*}$ & $-.10^{*}$ & $-.11 *$ & $-.40 * * *$ \\
\hline Sales growth & $.13 * * *$ & $.13 * * *$ & $.13 * * *$ & $.17 * * *$ \\
\hline$R \& D$ & $-.10 *$ & $-.09 *$ & $-.09 *$ & $.17 *$ \\
\hline Leverage & $-.48 * * *$ & $-.47 * * *$ & $-.49 * * *$ & $-1.59 * * *$ \\
\hline Industry median Tobin's q & $.59 * * *$ & $.59 * * *$ & $.58 * * *$ & $.62 * * *$ \\
\hline Year dummies & YES & YES & YES & YES \\
\hline Unaffiliated block own & -.14 & -.13 & -.15 & $.78+$ \\
\hline Cofounder own & $2.01 * * *$ & $1.90^{* * *}$ & $2.27 * * *$ & $9.02 * * *$ \\
\hline Insider own less founder & $-.28 \dagger$ & $-.25 \dagger$ & $-.26 \dagger$ & .62 \\
\hline Constant & $2.75 * * *$ & $2.73 * * *$ & $2.81 * * *$ & $2.82 * * *$ \\
\hline Observations & 11,645 & 11,645 & 11,645 & 11,645 \\
\hline Wald-chi ${ }^{2}$ & $2,723.30$ & $2,733.20$ & $2,748.32$ & \\
\hline Durbin-Wu-Hausman test & & & & $64.64 * * *$ \\
\hline Hansen J-test & & & & 1.24 \\
\hline Stock-Yogo test & & & & $7.56^{*}$ \\
\hline
\end{tabular}

$\dagger \mathrm{p}<.10 ; * \mathrm{p}<.05 ; * * \mathrm{p}<.01 ; * * * \mathrm{p}<.001$ 
Table 6. Results of Heckman (1979) selection model

\begin{tabular}{|c|c|c|}
\hline & (1) & (2) \\
\hline & $\begin{array}{l}\text { Selection } \\
\text { equation }\end{array}$ & $\begin{array}{l}\text { Valuation } \\
\text { equation }\end{array}$ \\
\hline Founder own & $.894 * * *$ & $-.849 * * *$ \\
\hline Founder own squared & -.632 & $1.506^{* * *}$ \\
\hline Wedge & .077 & $-.865 * * *$ \\
\hline Firm size & $.092 * * *$ & .004 \\
\hline Firm age & & $-.154 * * *$ \\
\hline $\mathrm{R} \& \mathrm{D}$ & $.186^{* * *}$ & $.202 * * *$ \\
\hline Leverage & & $-1.041 * * *$ \\
\hline Unaffiliated block own & & $-.468 * * *$ \\
\hline Industry median Tobin's q & & $.574 * * *$ \\
\hline Cofounder own & & $1.675 * * *$ \\
\hline Insider own less founder & & $-.618 * * *$ \\
\hline Sales growth & & $.150 * * *$ \\
\hline Firm age at IPO & $.003 * * *$ & \\
\hline Years since IPO & $-.139 * * *$ & \\
\hline Years since IPO squared & $.007 * * *$ & \\
\hline Industry sales growth & -.025 & \\
\hline Industry concentration & .252 & \\
\hline High tech dummy & .024 & \\
\hline Year dummies & & YES \\
\hline Constant & $1.177 * * *$ & $.890 * * *$ \\
\hline Observations & 11,615 & 11,615 \\
\hline
\end{tabular}

Note: This table has a lower number of observations than the others because we lose observations due to lagging ownership to predict survival 
Table 7. Results of regressions of leverage (multi-level Tobit), diversification and disproportionate board representation (Logit) on founder ownership

\begin{tabular}{|c|c|c|c|c|c|c|c|c|c|}
\hline & (1) & (2) & (3) & (4) & (5) & (6) & (7) & (8) & (9) \\
\hline & \multicolumn{3}{|c|}{ Leverage } & \multicolumn{3}{|c|}{ Diversification } & \multicolumn{3}{|c|}{ Disproportionate board repr. } \\
\hline Founder own & & $.04 \dagger$ & $-.20 * * *$ & & .01 & $.82 *$ & & $-2.20 * * *$ & $25.08 * * *$ \\
\hline Founder own squared & & & $.35 * * *$ & & & $-1.36^{*}$ & & & $-72.43 * * *$ \\
\hline Wedge & & .05 & -.02 & & -.44 & .06 & & $-8.03 * * *$ & $-4.87 \dagger$ \\
\hline Firm size & $.05 * * *$ & $.05 * * *$ & $.05 * * *$ & $.22 * * *$ & $.22 * * *$ & $.22 * * *$ & .02 & .01 & $.04 \star$ \\
\hline Firm age & -.01 & -.01 & -.01 & $.288 * * *$ & $.29 * * *$ & $.29 * * *$ & $-.57 * * *$ & $-.50 * * *$ & $-.38 * * *$ \\
\hline $\mathrm{R} \& \mathrm{D}$ & .01 & .01 & .01 & & & & $.21 * * *$ & .08 & $.23 * * *$ \\
\hline Leverage & & & & -.17 & -.16 & -.15 & $-1.01 * * *$ & $-.71 * * *$ & $-.47 * * *$ \\
\hline Industry median Tobin's q & & & & $-.18 * * *$ & $-.18 * * *$ & $-.18 * * *$ & & & \\
\hline Unaffiliated block own & $.08 * * *$ & $.09 * * *$ & $.08 * * *$ & $-.26 \dagger$ & $-.29 \dagger$ & $-.28+$ & $.51 * * *$ & $-.32 *$ & -.18 \\
\hline Cofounder own & -.06 & -.08 & .01 & $-1.26 \dagger$ & $-1.26 \dagger$ & $-1.74 *$ & $7.92 * * *$ & $9.95 * * *$ & $3.17 * * *$ \\
\hline Insider own less founder & $.05^{*}$ & $.06 * *$ & $.06 * *$ & .03 & .01 & .05 & $-4.87 * * *$ & $-5.96 * * *$ & $-6.14 * * *$ \\
\hline Collateral & $.20 * * *$ & $.20 * * *$ & $.20 * * *$ & & & & & & \\
\hline Cash ratio & & & & $-.64 * * *$ & $-.64 * * *$ & $-.62 * * *$ & & & \\
\hline EBIT & & & & $.30 * * *$ & $.29 * * *$ & $.29 * * *$ & & & \\
\hline NYSE & & & & $-.20 * *$ & $-.20 * *$ & $-.20 * *$ & & & \\
\hline Industry median leverage & $.56 * * *$ & $.55^{* * *}$ & $.56 * * *$ & & & & & & \\
\hline Industry percent diversified & & & & $.67 * * *$ & $.66 * * *$ & $.68 * * *$ & & & \\
\hline Constant & $-.30 * * *$ & $-.30 * * *$ & $-.28 * * *$ & $-3.08 * * *$ & $-3.08 * * *$ & $-3.14 * * *$ & $.58 *$ & $.75 * *$ & -.38 \\
\hline Year dummies & YES & YES & YES & YES & YES & YES & YES & YES & YES \\
\hline Observations & 11,645 & 11,645 & 11,645 & 11,645 & 11,645 & 11,645 & 11,645 & 11,645 & 11,645 \\
\hline Wald-chi ${ }^{2}$ & $1,417.40$ & $1,427.17$ & $1,465.48$ & & & & & & \\
\hline Pseudo-R-squared $^{\mathrm{a}}$ & & & & .19 & .19 & .19 & .08 & .11 & .25 \\
\hline
\end{tabular}


Figure 1. Relationships between founder ownership and firm value, leverage, diversification, and disproportionate board representation

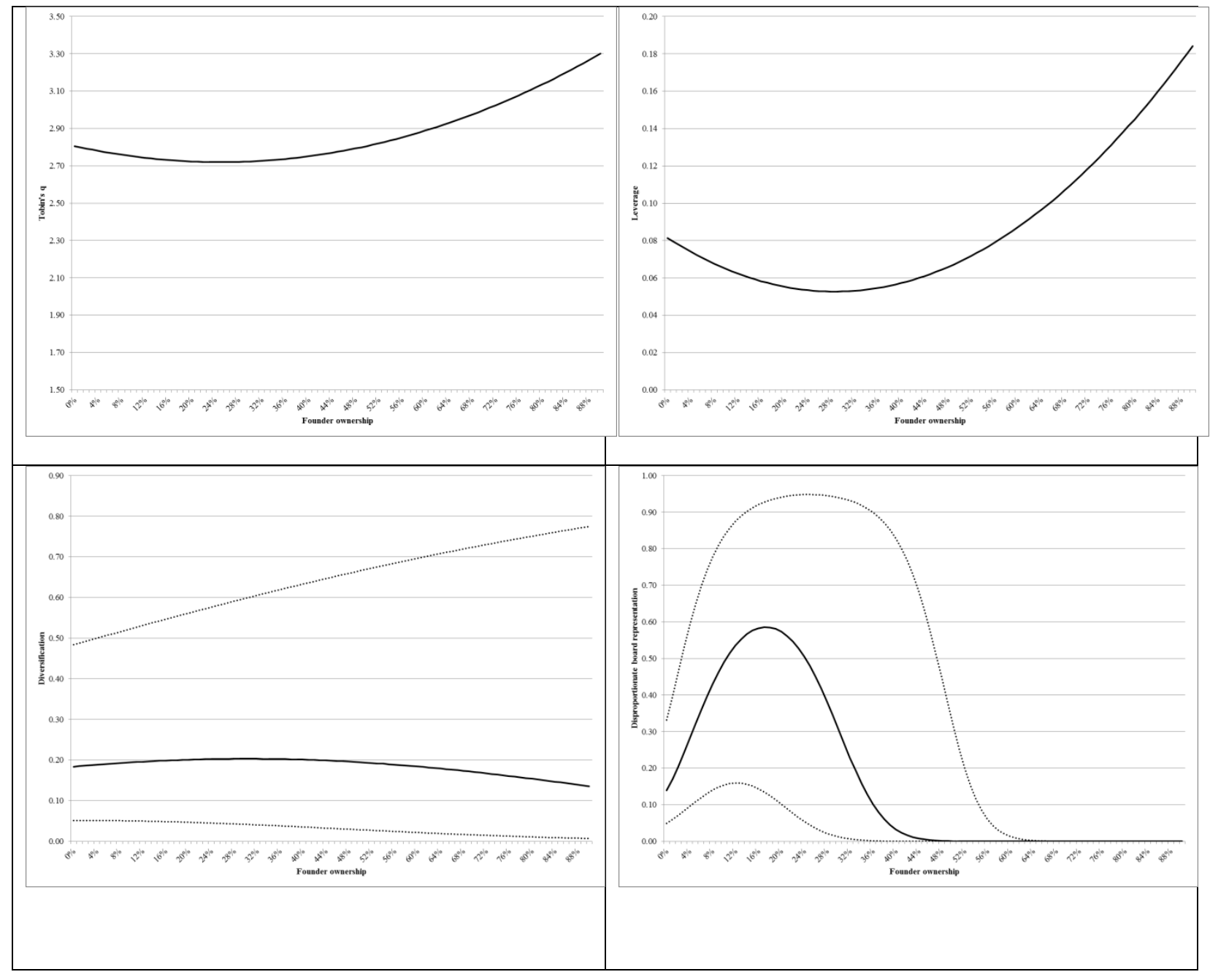

